\title{
Towards Decentralization in Indonesia: Electronic Government in te Vanishing of Distance: The Papua (Irian Jaya) Province Case
}

\author{
Irendra Radjawali \\ Bandung Institute of Technology, Bandung, Indonesia
}

radjawali@kompascyber.com

Keywords : Information and Communication Technology, Decentralization, Sustainable Development, Public Services, Local Government, Regional Autonomy, Poverty Alleviation, Community Empowerment, Participation in Development, Free Trade Area, Free Market, Electronic Government, Capacity Building

\section{Introduction}

Indonesia is facing a new phase in its development process. Where it had been established decentralization policy in development process starting at $1^{\text {st }}$ of January 2001, known as Regional Autonomy Rules. The Regional Autonomy gives more chances and power to the local government to manage their territory. There are 5 fields which are not to be decentralized: monetary, fiscal, security, religion, and foreign affairs. In several ways, this decentralization process gives a bigger power for the local government to plan their own development, the program, the financial aspect, the target, etc. But also in several ways, it needs a strong coordination between every local government in Indonesia to prevent overlapped program or targets to meet the national goals.

At present, there are now 30 provinces in Indonesia and 368 cities and municipalities in Indonesia. The Regional Autonomy Rules transfer a bigger power to the level of city and municipality. Since the decentralization is a new concept of development in Indonesia, it's very difficult to be managed. The biggest challenge is coordination among the local governments to prevent unnecessary competition between local governments. For example, from the 368 cities and municipalities in Indonesia, about 200 of them had proposed to build international standard harbors and ports, which is not effective at all. The problem is coordination, which could be conducted through the good implementation of Electronic Government System. We could also see in Indonesia, that this Regional Autonomy euphoria in every local government tends to let them catch the macro economy targets. Like Foreign Direct Investment. Every Local Government tries to attract investors to invest in their area, which still count on primary sectors like mining, and other natural resources sectors. But there's a main task that the Local Government should deliver to the people: Public services.

This paper tries to examine how the Information and Communication Technology will play a big role in

Material published as part of these proceedings, either on-line or in print, is copyrighted by Informing Science. Permission to make digital or paper copy of part or all of these works for personal or classroom use is granted without fee provided that the copies are not made or distributed for profit or commercial advantage AND that copies 1) bear this notice in full and 2) give the full citation on the first page. It is permissible to abstract these works so long as credit is given. To copy in all other cases or to republish or to post on a server or to redistribute to lists requires specific permission from the publisher at Publisher@InformingScience.org the new decentralization system in Indonesia. How it will deliver more public services, more coordination between the stakeholders, which are the government, the people, and the private sectors. How it will answer the big challenge, coordination, and how it will help the local government to cope with the globalization process that is marked with the regional Free Trade Zone? 
This paper takes the development process in West Papua (formerly Irian Jaya) province, the East region of Indonesia, where The Papua is one of the two provinces that get the Special Autonomy beside the Aceh Province. Papua has its own characteristics where they have so many natural resources; one of them is copper that had been exploited since 1970s by the Freeport Corporation. Sociologically, Papua also have so many ethnic groups (hundreds) which are very different in their customs and most of them still living in the primitive way. Papua also has a very challenging geography. Since there are high mountains, swamp area, rainforests, etc. The biggest challenge for Papua is the effort to raise the Human Resources Capacity but also in the other hand coping with the globalization process which marked with the regional free trade zone.

\section{Decentralization and Free Market Challenges}

\section{Regional Autonomy in Indonesia}

Indonesia is now in the middle of the transformation of power between the Central Government and the Local Government. Since it has been established the Law No. 22 / 1999 about the Local Go vernment. Adjustment had been made for political and technical targets. Politically, decentralization is the manifestation of the reformation process in Indonesia since we have the new order regime fall. But technically, there are so many preparations have to be made in order to the adjustment of this new policy effectively.

The concept of Regional Autonomy is to maximize the goals and targets and also prevent the difficulties of development process in Indonesia. Where citizen's demand could be realized and the delivery of public services is guaranteed, and also to keep the sustainability of national fiscal.

Regional Autonomy is the political phenomenon that is needed in the globalization and democratization era. And also to answer the future challenge entering the free trade and free market era, which marked by the emerging of the regional corporation, the changing of pattern and system of information dissemination.

Through this Regional Autonomy, it is expected that every local government could become more independent in the term of planning their own development process. Local governments are expected to be able to play their roles in opening the potencies of Local Economic Development and managing their financial. They are also expected to be able to improve their work, and be able to responsible their work to the people / citizens and to the central government.

To make the Regional Autonomy work well, there has to be a power decentralization and transfer of authority as real as it could be and full of responsibility, proportionally, against corruption, collusion and nepotism. And also there are hints and pre-conditions to be fulfilled that are :

- The quality of human resources

- Financial resources

- Supporting facilities for the Local Government

There are only 5 fields which are not to be decentralized: monetary, fiscal, security, religion, and foreign affairs politic. But the Autonomy gives a bigger authority for local government to conduct the Foreign Direct Investment into their area. It means that every local government is free to deal with foreign investors in their own plan. In some ways, it will accelerate the development process in every region. But also there will be problem when the coordination aspect not working. Because there will be a bad competition among the local governments. (Widjaja, HAW, 2001)

In this way, the Information and Communication Technology could play a significant role. Which not just answering the challenge regarding the coordination but also answering the challenge regarding the public services, regarding the human resources capacity building, regarding the good governance aspect, 
and also the important one is coping with the Free Market and Free Trade era. Which will started in 2003 with the AFTA (Asean Free Trade Area).

\section{Special Autonomy in Papua}

Special autonomy for Papua was given in 2001. There are 2 provinces in Indonesia that accepted this special autonomy, which are Papua and Aceh. Special Autonomy for Papua was born after Papua asked for their freedom and asked for their independence from Indonesia. The Government offers the Special Autonomy as the solution, which is accepted in 2001. The significant aspect in special autonomy for Papua is, the Papua People Assembly, which has the highest authority in Papua in making decision regarding the development process in Papua.

The significant aspect in special autonomy for Papua, is also regarding the financial resources, which Papua has the biggest proportion of development fund from the national level development fund, that is about 1,530 billion rupiahs. The Governor of Papua, Mr. JP Solossa stated in front of the Local Legislative in Jayapura, Papua, that there are 4 priorities aspects of development during the Special Autonomy in Papua, which are:

- Education and Human Resources Capacity Building, took 30\% of Special Autonomy fund.

- Health, took $15 \%$ of Special Autonomy fund.

- Local Economic Development, and,

- Transportation Infrastructure

The Local Government realized exactly that their biggest challenge of running the development process is the human resource capacity which influences the institutional capacity. They have to deliver good public services but they also have to increase the people's capacity building. (Kompas, 2002)

Papua also have a special concept of their development process; this is the three institutions concept, which is the synergy development process through the three institutions, the Government, the Church, and the ethnical institution. It has been found that in Papua, there are 329 ethnics with their own language, their own custom, which are very different from one another. It is so difficult to communicate between ethnics, until now. They need translator between the ethnic groups. (GMKI, 2000)

Here is the importance of ethnical institutions and Church. Where both of them could enter to the people of Papua through the "cultural - social - anthropology". And then it is also important that the government should know exactly the dynamic of Papua people through that both institutions. While in the development process, there is also concept of three stakeholders which are government, citizens, and private sectors. Here is the hard work of Papua Local Government, where they have to deal legally with citizens and private sectors to develop their area to reach their prosperity, but they also have to deal with the diversity and the lack of capacity of people in Papua.

The Government of Republic of Indonesia in the process of development of Papua and also Eastern Indonesia Region, had set up several tasks. These tasks mainly are the tasks for attracting Foreign Direct Investment, through the exploitation of Natural Resources in Papua. The latest one is the Liquid Natural Gas (LNG) project called Tangguh LNG in Papua. It is the $3^{\text {rd }}$ largest LNG in Indonesia, which turn Indonesia in to the leading of the LNG producer in Asia Pacific. It is the joint project with British Petroleum Indonesia.

The critical point is, it is the challenging work for Papua Local Government. In one side, they have to cope with the development acceleration in the term of macro economic indicator, dealing with Foreign Investor which needs a qualified investment. Like the good political condition, good governance, qualified people, etc. But in the other side, the Local Government of Papua has to face the lack of capacity of 
Papua People, the lack of institutional capacity, which is could become big problem with development process.

Papua province has now 28 cities and municipalities which laid on the difficult and hard geographic condition. For example, from one local city government to communicate with the county within their area, it took 6 days of travel through the river, forest and etc. While in the heavy natural resource based industrial area like Timika city, the Freeport's city, it is like living in the well developed country with all the facilities provided. Freeport is Multinational Corporation dealing in the mining business.

This paper tries to examine how important the Information and Communication Technology in answering these challenges. ICT is not the tool for attracting Foreign Investors, but It also tool for good go vernance in Papua, tool for capacity building in Papua, tool for poverty alleviation, tool for community building, tool for cultural, ethnical, custom, preservation, etc. It depends on how the Local Government should deal with this technology, and realize as soon as possible, that this technology, in the right hand, will answer several of their challenges effectively.

The digital divide has to be erased in a certain period. If the local government successful to manage the using of the Information and Technology in their development process, it will be a great accelerator to reach the people prosperity and place prosperity. The big question for the Local Government in Papua is not are we ready for that but start today or left behind.

\section{The Challenge of Asean Free Trade Agreement (AFTA)}

Year 2003 will be the starting point of AFTA (ASEAN Free Trade Area), a free trade system in South East Asian Region. With this policy, there will be no rules to conduct the limitation of importing and exporting products, services, etc. Several of the challenges are: the human resources capacity, regulation capacity, product capacity, institutional capacity.

The protection for local product could be achieved by implementing standardization of local products. But it would not give a significant change to the development process in the future. Because the important think of Free Trade is the ability to cope and deal with the global competition. Which couldn't be reached just by protecting products. Instead of protecting products, there have to be major significant changes in the system, including the institutional, government, economy, social, etc.

In Indonesia case, the problem of development is always on the inefficiency process. Where there are a long and huge bureaucracy which is not really transparent to the people. This condition could be the biggest problem for Indonesia to cope with Free Trade and Free Market system.

\section{Information and Communication Technology in Development Process in Papua, Indonesia}

In this case, this paper try to describe the importance of Information and Communication Technology as supporting tools for the development process and the difficulties of implement it in the government sectors. As we might agree that Information and Technology for government could be represented with the Electronic Government system which will give a transparent process of governing, development, and also cut off the long bureaucracy, which one of the important condition before ready to compete in global era.

With geographical, cultural and social challenges that the Local Government of Papua have, they should find the proper solution for their own goals. I believe that the proper solution is using the Information and Technology through the implementing of the Electronic Government to cope with these revolutionary changes. Delivering the best services to the citizens is the most important goal of the development process in Papua. While it could be done through the building of people's capacity. Like it has been 
stated in the previous page, that the priority for Local Government in Papua is building the people's capacity through the education.

I believe that a strategic implementation of Information and Communication Technology will be a good solution either to deliver the best services for the public, and also building the people's capacity. The EGovernment system would not just cut the bureaucracy lines, or make the process transparent, but it will also force the people to cope with the progress of Information Technology, it will force the people to start themselves to think efficiently and give them chances to access sources of information all over the world. It will open the people minds and ready to cope with the competition system.

In fact, competition will need government help to become established. Big networks are more useful to customers than small ones. (Cairncross, 1997)

As Francess Cairncross stated that competition will need government help to become established. I describe competition as a system involving not just institutionally but also individually. So, the important key is how the government, in this case is the Local Government of Papua should have a big leap by implementing the Information Technology through the E-government to deliver the best services to their citizens. It would reduce the time of communication between municipalities, between counties, between citizens. Since there are 329 ethnics with different languages, the Information Technology will allow inter-region communication through the multimedia system, and again serving the best for the people.

In my opinion, the first step to be made is institutionalized the Information and Technology into the Development Planning Institution, as we can see the diagram shown in Figure 1.

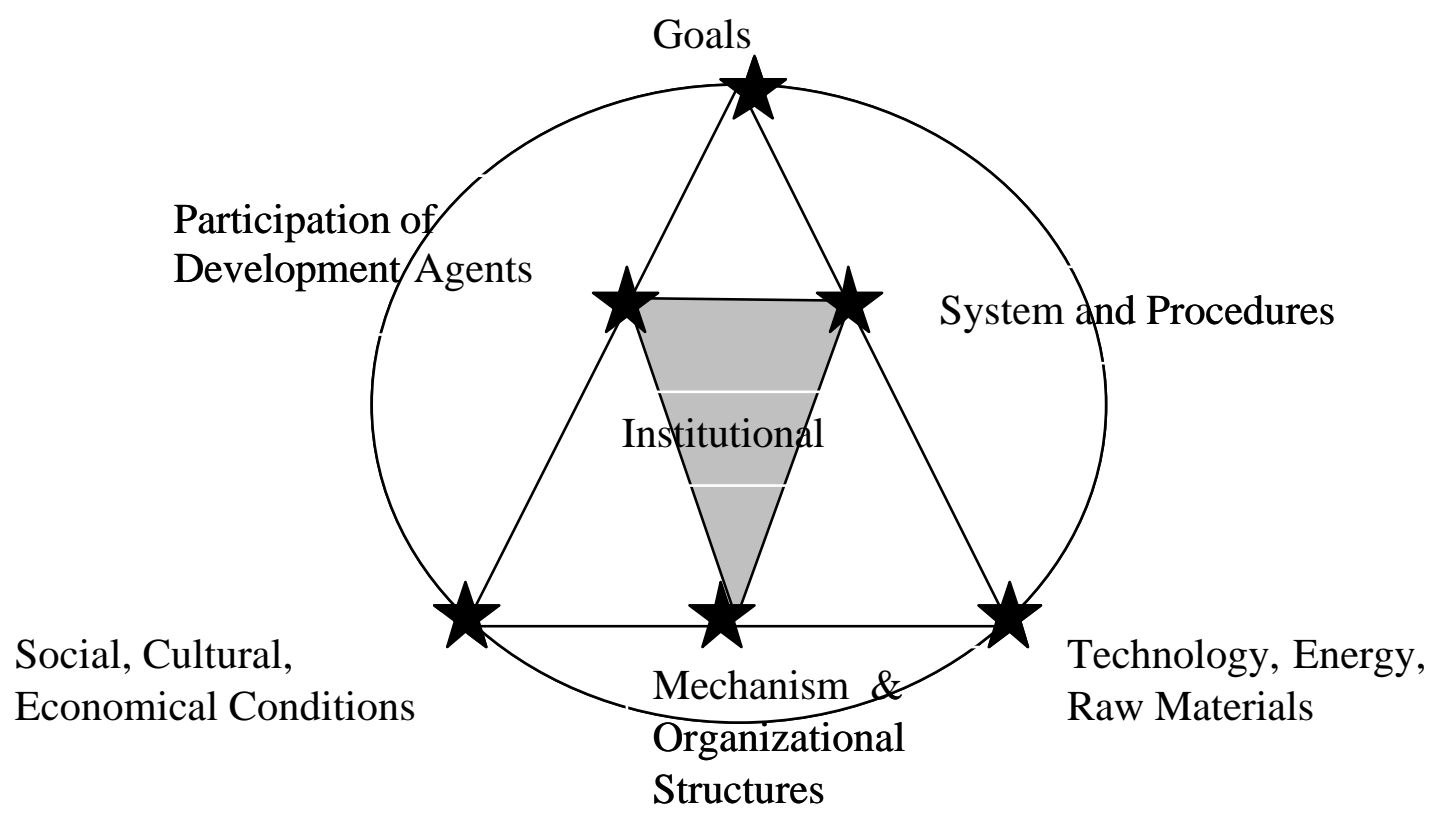

Figure 1. The Development Planning Institution

(Ostrom et. al , 1994 ) 


\section{Conclusion}

This paper is only the preliminary paper towards the research and projects that will be conducted in Papua, Indonesia regarding the acceleration of the development process through the implementation of Information and Technology infrastructure in meeting the development goals. I realize that this paper is still in the strategic level. But I also believe that the awareness of the importance of using Information and Technology as the tool to deliver services coping with development process and coping with the free trade era has to be started.

Local Government of Papua has to be informed that they are facing the globalization instead of they are also facing the lack of people capacity. The three pillars of development in Papua, the government, the church, and the ethnic institution could work with synergic to develop the Papua towards the people and place prosperity.

The key of decentralization in Papua is not just the amount of fiscal or financial sectors, but also the readiness to cope with globalization which could be reached through Information and Technology. Which I believe is the revolutionary way to cope with the changing world.

The Real Challenge is not Are we Ready or not, but The real challenge is time! It has to be now or left behind for hundreds of years.

\section{References}

Widjaja HAW. (2002). Regional Autonomy, PT Raja Grafindo Persada, Jakarta

PT.Kompas Media Nusantara (2002), KOMPAS Newspaper

Ostrom, Elinor, Gardner. R., Walker. J., (1994). Rules, Games and Common-Pool Resources, Michigan : The University Michigan Press

Sekolah Tinggi Ilmu Ekonomi Ottow dan Geissler Jayapura, (2000), Kemitraan Kerja Tiga Tungku, Panitia Seminar dan Lokakarnya

Castells, M. (1996), The Information Age : Economy, Society, and Culture, Volume I, The Rise of The Network Society, Blackwell Publishers.

Castells, M. (1997), The Information Age : Economy, Society and Culture, Volume II, The Power of Identity, Blackwell Publishers.

Sassen, S. (2002), Global Networks, Linked Cities, Routledge. 